\title{
Rapid Method for Greywater Treatment and Their Potential Reuse in Agriculture
}

\author{
Eman Mahmoud El Qrenawi1 ${ }^{1}$ Ibrahim EL-Nahhal'2, Mohamad R. Al-Agha1, Yasser El-Nahhal ${ }^{*}$ \\ ${ }^{1}$ Department of Environmental Science, Faculty of Science, The Islamic University-Gaza, Gaza, Palestine \\ ${ }^{2}$ Université de Toulon, Aix-Marseille Université, La Garde, France \\ Email: ${ }^{\star}$ __el_nahhal@hotmail.com
}

How to cite this paper: El Qrenawi, E.M. EL-Nahhal, I., Al-Agha, M.R. and El-Nahhal, Y. (2022) Rapid Method for Greywater Treatment and Their Potential Reuse in Agriculture. American Journal of Analytical Chemistry, 13, 20-38.

https://doi.org/10.4236/ajac.2022.132003

Received: January 7, 2022

Accepted: February 22, 2022

Published: February 25, 2022

Copyright (c) 2022 by author(s) and Scientific Research Publishing Inc. This work is licensed under the Creative Commons Attribution International License (CC BY 4.0).

http://creativecommons.org/licenses/by/4.0/

\begin{abstract}
Greywater, a type of wastewater, may be hazardous to human health and ecosystems. Greywater is a large fraction of wastewater that needs adequate attention for remediation and reuse in the agricultural sector so that a part of the water problem can be sorted out. This study aims to develop a rapid method for greywater treatment and reuse in agriculture. A microfilter consisting of sand, clay, organo-clay, charcoal, and biochar was designed and tested for greywater treatments. Biological Oxygen Demand (BOD), Chemical Oxygen Demand (COD), Total Kjeldahl Nitrogen (TKN), Total Dissolved Salts (TDS), Electric Conductivity (EC), turbidity and $\mathrm{pH}$ values were measured before and after using the microfilter. Results showed tremendous removal efficiency of BOD, COD, TKN, by using the developed microfilter. The microfilter was also effective in treating and placing $\mathrm{pH}, \mathrm{EC}$ and TDS in the acceptable range for suitable agricultural use. Using the treated greywater for irrigation in corn, tomato seedlings showed increased growth compared with the control group (plants irrigated with tap water). This microfilter treatment was economical, safe, easy to handle and easily applicable. These encouraging results suggest the application of this method in many countries for solving the water scarcity problem.
\end{abstract}

\section{Keywords}

Greywater, Microfilter, Sea Sand, Organoclay, Biochar, Charcoal, Sawdust

\section{Introduction}

Gaza Strip, a densely populated area suffers from a deficit in drinking water due to extensive use of groundwater in the agricultural sector and domestic purposes [1].

Domestic uses of water in the Gaza Strip reach about $96.308 \mathrm{~m}^{3}$ in 2017, the 
quantity is expected to increase due to population growth in Gaza [2].

Greywater is defined in this study as the domestic wastewater generated in houses and/or offices except that generated in the wastewater from toilets. It includes wastewater from baths, showers and hand basins to kitchen sinks and laundry machines and does not contain wastewater from the toilet [3].

In general, wastewater production represents $80 \%$ of total water consumption, whereas greywater represents $50 \%-80 \%$ of household wastewater [4]. Wastewater treatment facilities are not working at full capacity in the Gaza Strip due to the lack of power, and diesel oil. This may result in discharging untreated or partially treated wastewater to the sea. So far, greywater is discharged into aquatic systems mixed with wastewater because there is not a separated effluent system. This leads to increased turbidity of aquatic systems, oxygen depletion, as well as microbial and chemical contamination. Greywater treatment is the process by which effluent from domestic residues, commercial properties and industrial and agricultural processes is filtered and/or undergoes biological or chemical processes for removing harmful solids and other types of contaminants [5]. It may contain pathogens, parasites, detergents and soap [6].

Accordingly, it is necessary to search for advanced methods for greywater treatment in Gaza and make it safe and environmentally acceptable for agricultural reuse.

Greywater treatment is an urgent need to conserve freshwater for other potable uses. It is necessary to treat greywater before it can be used for crop irrigation. Complete information about greywater treatment in Gaza is not available and current treatment processes are nearly conventional. The aim of this work is to develop advanced methods for greywater treatment in Gaza. The methodology of this work is based on using washed sea sand mixed with an active material such as charcoal, biochar, organoclay, and sawdust and backed in a microfilmter.

\section{Materials and Methods}

\subsection{Collection of Greywater}

Greywater samples were collected from several houses, laundry washing machine by personal communications and mixed together to form a representative greywater of the location. The physico-chemical properties of these combined samples were recorded. The samples were kept under an aerobic condition to avoid any fermentation or biochemical degradation before performing the experiments.

\subsection{Biochar Production and Determining Its Physical Properties}

Dried leaves of figs (Ficus carcica) and lemon (Olea europaea) were collected and pyrolyzed in absence of oxygen using Steam Pressure cooker for 20 minutes, then air dried and crushed using mortar and pestle followed by sieving on $\leq 0.002 \mathrm{~mm}$ mesh sized sieve, so it turns into a powder. Figure 1 shows a photo 


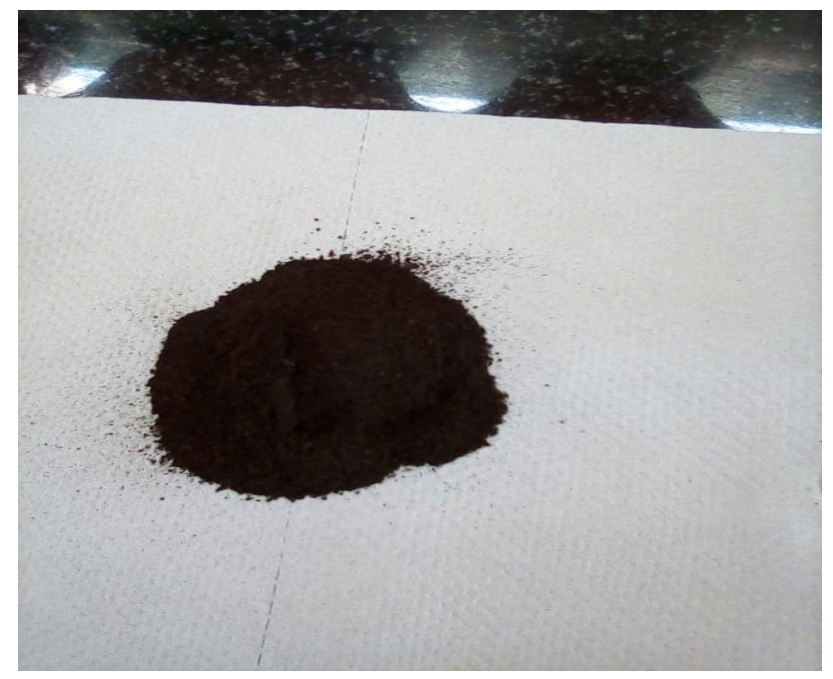

Figure 1. Biochar powder after sieving.

of produced biochar.

\subsection{Activating the Produced Biochar}

Certain amount (30 g air dry sample) of the produced biochar (Figure 1) was soaked with concentrated sulfuric acid for 48 hours and moved to heating under reflux for 8 hours. The mixture was cooled to the room temperature and washed several times with distilled water until the washing water has no sign of acidity. Then, the biochar was centrifuged to remove water. The solid biochar was heated at $105^{\circ} \mathrm{C}$ for 48 hours. Then, the product was cooled down to room temperature and kept in dry plastic bottle for further uses. This product is called activated biochar.

\subsection{Determination of Some Physicochemical Properties}

\subsubsection{Bulk Density}

Bulk density is defined by the volume of the container used to hold the sample, this volume includes pore space within and between the sample particles. To determine density, a known weight and volume of charcoal is measured inside the container and divided by its mass [7].

$$
\text { Bulk density }=\frac{\text { weight }(\mathrm{g})}{\operatorname{volume}\left(\mathrm{cm}^{3}\right)}
$$

\subsubsection{Water Holding Capacity}

The water holding capacity is determined by the amount of water held in the sample vs. the dry weight of the sample at atmospheric temperature and pressure [8].

So it is determined by adding $10 \mathrm{~g}$ of biochar in a filter paper over a conical flask followed by pouring $10 \mathrm{ml}$ of distilled water over it. Then measure the remained volume of water after 30 minutes. Then, water holding capacity is determined by substacting the collected water volume from the initial added one according to Equation (2): 


$$
\text { Water holding capacity }=\frac{V i-V c}{V i}
$$

where $V i$ and $V c$ are the initial added water volume and the collected one after 30 min respectively.

\subsubsection{Porosity}

Porosity is defined as the ratio of the volume of pores to the volume of bulk particles and is usually expressed as a percentage [9].

To determine porosity, a known volume and weight of biochar is added to a $25 \mathrm{ml}$ volumetric flask. Then, the electronic balance was transferred to a zero value by pressing tare button in order to weight the amount of water added up to the mark of the volumetric flask. This step enables the determination of the actual weight of water which in turn equals to the volume of water added.

\subsubsection{Calculation}

Total volume of conical flask ( $V t$ ) equals volume of sediments at the atmosphere ( Vsa) plus the remaining empty volume of the conical flask ( $V r$ ) that has to be filled with distilled water, which equals the volume of solid particles in water $(V s w)$ plus the volume of water added $(\mathrm{Vm})$. Void volume can be obtained from Equation (6). More details are shown in Equations (3)-(8).

$$
\begin{gathered}
V t=V s a+V r \\
V r=V s w+V w \\
V w=M w \\
V v=V s a-V s w \\
V s w=V t-M w \\
\text { Particle dinsity = paricle mass } / V s w
\end{gathered}
$$

Porosity $=$ Bulk volume of biochar-particle volume of biochar

\subsection{Adsorption Laboratory Experiments}

Eighteen (18) conical flasks containing $25 \mathrm{ml}$ of greywater were subdivided into 6 groups (three replicate each). Charcoal concentrations, 0, 30, 45, 60, 75, and 90 mg were added separately to each group. Similar concentrations were used for organoclays. The flasks were left for 3 days under continuous horizontal shaking. Then $\mathrm{pH}, \mathrm{EC}$ and TDS values were determined. The organoclay used in this test was Benzyl tributyl ammonium organoclay adsorbed on $0.5 \mathrm{mmol} / \mathrm{g}$ of clay (BTBA0.5). It was prepared according to a previous procedure [10] [11].

\subsection{Development of Microfilters}

Twenty-five plastic pipes, $4 \mathrm{~m}$ length and $1.72 \mathrm{~cm}$ diameter were purchased from a local market in Gaza. The pipes were subdivided into five groups as follows: Group A (control group) where the pipes were filled with sand only; Group B, the pipes were filled with sand mixed with biochar; Group C, the pipes were filled with sand mixed with charcoal; Group D, the pipes were filled with sand mixed 
with organoclay and Group E, the pipes were filled with sand mixed with sawdust only. All sand mixtures contained active materials (biochar, charcoal, organoclays, sawdust) at a rate of $0.5 \%(\mathrm{w} / \mathrm{w})$. The sand used in this study was collected from the sea shore, air dried, sieved through $2 \mathrm{~mm}$ mesh and washed with distilled water to remove salinity before its use. Silver nitrate was used to check for salinity removal [12].

The needed amount of sand in each pipe was calculated according to the general cylinder volume $(\pi \mathrm{r} 2 \mathrm{~L})$. In general, appropriate amount of sea sand was mixed separately with $0.5 \%$ w/w of either biochar, charcoal, organoclay, or sawdust. The control group contains sea sand only. Each group of pipes were connected to $20 \mathrm{~L}$ plastic container and operated at a flow rate of $10 \mathrm{ml} / \mathrm{min}$ which remained constant through experiment. The flow rate of greywater was constant in all pipes. So far, the schematic diagram of the microfilter is shown in Figure 2.

The physical and chemical parameters of the greywater were determined before and after system performance. The following properties: turbidity, EC, TDS, $\mathrm{pH}$ were determined using digital devices. The BOD values were determined by

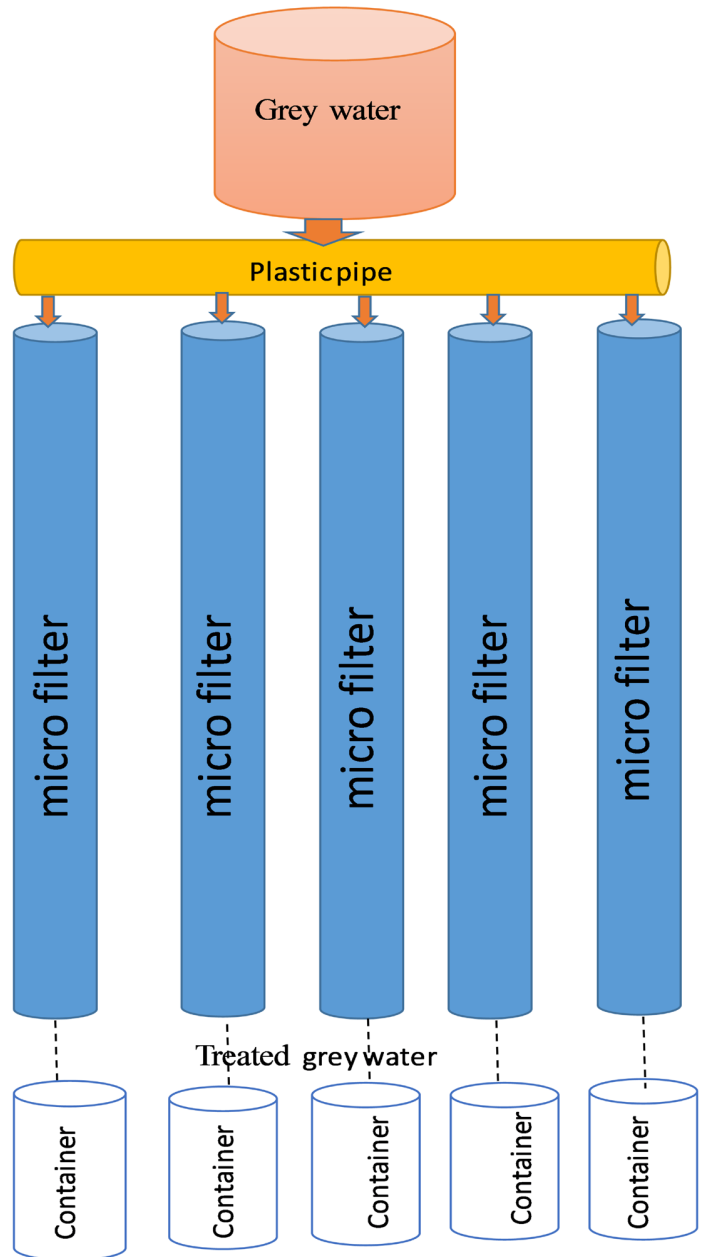

Figure 2. Schematic diagram of the micro-filters. 
Oxi-top machine. The COD and TKN were determined according to El-Nahhal et al. [13].

Development of a Layer Structure and a Longer Microfilter The idea behind this development is based on collecting all materials mentioned above in a longer column having the same flow rate of greywater. Under this condition, greywater was passed through different materials of different adsorbing capacity. This may enable high removal of pollution in greywater.

\subsection{Determination of Total Kjeldahl Nitrogen (TKN)}

Ten ml greywater sample was collected from each treatment and transferred to a digestion tube containing $10 \mathrm{ml}$ sulfuric acid and copper sulfate. The samples were heated up to $520^{\circ} \mathrm{C}$ for four hours in order to have a clear solution in each digestion tube. Then, the samples were cooled to room temperature and moved to Kjeldahl tube for extraction under basic media and $25 \mathrm{ml}$ of boric acid reagent was used to catch produced ammonia during extraction. The ammonium borate was titrated with $0.1 \mathrm{~N} \mathrm{HCl}$ up to changing color from wine read to blue one [14].

\subsection{Determination of Chemical Oxygen Demand (COD)}

Greywater samples were collected and mixed well then $2 \mathrm{ml}$ sample was transferred to COD tubes. Then, each tube received $2.8 \mathrm{ml}$ of potassium dichromate and $36-40 \mathrm{mg}$ of mercuric sulfate $\left(\mathrm{HgSO}_{4}\right)$ salt is added. Then, the tubes were transferred to the COD reactor and the samples were headed 2 hours at $160^{\circ} \mathrm{C}$ for complete digestion. Then, the tubes were cooled and their absorbance at 620 $\mathrm{nm}$ was measured using spectrophotometer.

The reaction of dichromate in acidic solution may be represented as:

$$
\mathrm{Cr}_{2} \mathrm{O}_{7}^{-}+14 \mathrm{H}^{+}+6 \mathrm{e}^{-} \rightarrow 2 \mathrm{Cr}^{3+}+7 \mathrm{H}_{2} \mathrm{O}
$$

while oxidation by oxygen can be represented as:

$$
\mathrm{O}_{2}+4 \mathrm{H}^{+}+4 \mathrm{e}^{-} \rightarrow 2 \mathrm{H}_{2} \mathrm{O}
$$

Since each $\mathrm{Cr}_{2} \mathrm{O}_{7}^{-}$ion consumes 6 electrons and since each $\mathrm{O}_{2}$ molecule consumes 4 electrons, then 1 mole of $\mathrm{Cr}_{2} \mathrm{O}_{7}^{-}$is equivalent to $6 / 4=1.5$ moles of 02 .

\subsection{Determination of Biochemical Oxygen Demand (BOD)}

\section{OxiTop Method}

Ten $10 \mathrm{ml}$ greywater samples were transferred to dark black measuring beakers under continuous magnetic stirring for five days. The measuring bottles were kept for 5 days at $20^{\circ} \mathrm{C}$. The sample was continuously stirred during the five days [15].

\subsection{Influence of Greywater on Plant Growth}

Tomato seeds (Cucumis sativa) and corn seeds (Zea mays) were used as test plants 
to investigate the influence of greywater on plant growth. In this test, each plant had three treatments. In control group, pots received tap water, Group two, pots received untreated greywater, Group three, pot received treated greywater. The pots were kept for 4 weeks under experimental conditions then, growth parameters (plant height $(\mathrm{cm})$; growth factor (GF) and plant appearance were taken as indicators of greywater influence on plant growth [16] [17].

\subsection{Data Analysis}

Each experiment consisted of five replicates, average and standard deviation of each parameter such as TKN, BOD, COD, turbidity, $\mathrm{pH}$, salinity were calculated for each tested materials. Analysis of variances among treatment was conducted to test for differences among treatments. P-value $\leq 0.05$ indicates significant differences [18] [19] [20].

\section{Results and Discussions}

Greywater used in this study included water from showers, bathtubs, sinks, kitchen, dishwashers, laundry tubs, and washing machines. It commonly contained soap, shampoo, toothpaste, food scraps, cooking oils, detergents and hair. Greywater treatment is the process by which effluent if is filtered and/or undergoes biological or chemical processes for removing harmful solids and other types of contaminants [5]. Our idea behind the development of an advanced microfilter is based on using five components: sea sand, biochar, charcoal, organoclay and sawdust either separately or jointly together in one microfilter. The idea behind using sea sand is that sea sand has fine particle size in the range of $0.63-0.02 \mathrm{~nm}$ [21]. This range of particle size may enable the formation of different microspores that can act as microseives for low volume of suspended organic matter in greywater. In addition, sand filter has been shown to reclaim wastewater in Gaza [22]. Additionally, the use of biochar in this study was based on its high adsorption capacity, low cost materials, easiness to be produced elsewhere by pyrolysis, consequently high ability to remove organic pollutants [23]. Furthermore, activated charcoal has shown the ability to adsorb organic and inorganic pollutants from aqueous solutions due to high surface area, a microporous structure [24] [25]. On the other hand, charcoal has the ability to lower the hydraulic conductivity of soil consequently, improving the filteration rate [26]. Moreover, the use of organoclay complexes in greywater treatment is due to their adsorption capacity [27]-[34], easy preparation [10], stability under different salinity levels [28] and ability to remove environmentally toxic anionic metals as chromate, ferricyanide and arsenate [35]. Recently, organoclay comples showed great ability to extract low concentrations of cyanotoxin [36], and pesticide residues [33] from water samples. Moreover, sawdust was used in our study due to its ability to remove dyes, oil, toxic salts, ammonia and heavy metals [37]. The schematic diagram of microfilter (Figure 2) clearly shows the easiness of construction and application for greywater treatment.

Physical properties of produced biochar are shown in Table 1. 
It is obvious that biochar has a low bulk density $\left(0.42 \mathrm{~g} / \mathrm{cm}^{3}\right)$ comparing with sand $\left(1.6 \mathrm{~g} / \mathrm{cm}^{3}\right)$. It has also a low water holding capacity $(0.32 \mathrm{~g} / \mathrm{g})$ comparing with wood cellulose $(3.5 \mathrm{~g} / \mathrm{g})$. In contrast, biochar has a high porosity $(6.77 \Phi)$ in comparison with fine sand $(0.29-0.46 \Phi)$. These properties enhance adsorption capacity of biochar and hence enhance filtration rate and filtration efficacy. It has been previously reported that biochar has better adsorption capacity than activated charcoal [38].

\subsection{Physical Results of Adsorption Experiments}

Effects of charcoal and organoclay in changing $\mathrm{pH}, \mathrm{EC}$ and TDS are presented in Table 2. It can be seen that low or medium concentration of charcoal and organoclay was the best in removing TDS and EC. High concentrations of charcoal and organoclay used did not significantly improve the results. The explanation of these results is that charcoal and organoclays tend to form aggregate in the solution and precipitate down whereas at low concentrations (e.g 30, $45 \mathrm{mg} / \mathrm{L}$ ) charcoal and organoclay remained as suspended material in the solution consequently, more adsorption was obtained. Our results are in agreement with previous report [24] which found similar results with other cases.

It can be noticed that TDS was best removed with $30 \mathrm{mg}$ charcoal and organoclay/L. Increasing the concentration did not significantly improve the removal efficiency. The explanation of these results is that at low concentrations (e.g., 30 $\mathrm{mg} / \mathrm{L}$ ) the material is better suspended in water than at high concentrations and become in contact with the dissolved materials. Consequently, higher adsorption and removal efficiency may be obtained. In contrast, at a high concentrations of

Table 1. Physical properties of the made Biochar.

\begin{tabular}{cc}
\hline Physical property & Average \pm stdv \\
\hline Bulk density $\mathrm{g} / \mathrm{cm}^{3}$ & $0.4221 \pm 0.01$ \\
Water holding capacity $\mathrm{g}($ water $) / \mathrm{g}($ biochar $)$ & $0.326 \pm 0.01$ \\
Porosity $(\Phi)$ & $6.778 \pm 0.24$
\end{tabular}

Table 2. Physical parameters of graywater after treatment with different concentrations of charcoal and organoclays (average \pm stdev).

\begin{tabular}{|c|c|c|c|c|c|c|c|c|c|c|c|c|}
\hline \multirow{2}{*}{ Test } & \multicolumn{6}{|c|}{ Charcoal concentration (mg/l) } & \multicolumn{6}{|c|}{ Organoclay concentration (mg/l) } \\
\hline & 0 & 30 & 45 & 60 & 75 & 90 & 0 & 30 & 45 & 60 & 75 & 90 \\
\hline $\mathrm{pH}$ & $\begin{array}{c}8.05 \\
\pm 0.10\end{array}$ & $\begin{array}{c}8.59 \\
\pm 0.22\end{array}$ & $\begin{array}{c}8.7 \\
\pm 0.1\end{array}$ & $\begin{array}{c}8.22 \\
\pm 0.16\end{array}$ & $\begin{array}{c}8.21 \\
\pm 0.18\end{array}$ & $\begin{array}{c}8.29 \\
\pm 0.06\end{array}$ & $\begin{array}{c}8.22 \\
\pm 0.01\end{array}$ & $\begin{array}{c}8.16 \\
\pm 0.03\end{array}$ & $\begin{array}{c}8.2 \\
\pm 0.05\end{array}$ & $\begin{array}{c}8.08 \\
\pm 0.04\end{array}$ & $\begin{array}{c}8.17 \\
\pm 0.09\end{array}$ & $\begin{array}{c}8.32 \pm \\
0.12\end{array}$ \\
\hline $\mathrm{EC} \mathrm{ms} / \mathrm{cm}$ & $\begin{array}{c}2.66 \\
\pm 0\end{array}$ & $\begin{array}{c}2.59 \\
\pm 0.12\end{array}$ & $\begin{array}{c}2.59 \\
\pm 0.03\end{array}$ & $\begin{array}{c}2.7 \\
\pm 0.06\end{array}$ & $\begin{array}{c}2.42 \\
\pm 0.09\end{array}$ & $\begin{array}{c}2.59 \\
\pm 0.05\end{array}$ & $\begin{array}{c}4.7 \\
\pm 0.02\end{array}$ & $\begin{array}{c}3.76 \\
\pm 0.09\end{array}$ & $\begin{array}{c}4.16 \\
\pm 0.012\end{array}$ & $\begin{array}{c}4.13 \\
\pm 0.05\end{array}$ & $\begin{array}{c}4.12 \\
\pm 0.06\end{array}$ & $\begin{array}{c}4.18 \\
\pm 0.08\end{array}$ \\
\hline $\mathrm{TDS} \mathrm{mg} / \mathrm{l}$ & $\begin{array}{c}1990 \\
\pm 29.4\end{array}$ & $\begin{array}{c}1933 \\
\pm 78.5\end{array}$ & $\begin{array}{r}1963 \\
\pm 37.7\end{array}$ & $\begin{array}{c}2130 \\
\pm 28.3\end{array}$ & $\begin{array}{c}2006 \\
\pm 36.81\end{array}$ & $\begin{array}{l}2013 \\
\pm 4.7\end{array}$ & $\begin{array}{r}1920 \\
\pm 4.71\end{array}$ & $\begin{array}{c}1700 \\
\pm 37.7\end{array}$ & $\begin{array}{c}1720 \\
\pm 14.14\end{array}$ & $\begin{array}{c}1720 \\
\pm 16.3\end{array}$ & $\begin{array}{c}1720 \\
\pm 37.4\end{array}$ & $\begin{array}{c}1720 \\
\pm 14.14\end{array}$ \\
\hline
\end{tabular}


suspended materials, the materials tend to aggregate together and forming a larger particle that precipitate down in the solution concequently, low adsorption and removal efficiency were observed. According to these results, the low test concentration is the best.

\subsection{Microfilter Technique}

Effects of microfilter in removing TKN, BOD and COD are shown in Table 3.

It can be seen that microfillter containing organoclay was the best in removal of nitrogenous compounds as indicated by low TKN value. It removed about $91 \%$ of nitrogenous compounds present in greywater. So far, sawdust was in the second order in removing TKN. Sawdust removed about $88 \%$. Microfilters containing Biochar and charcoal removed high percentage of TKN, 70.3\% and $73.1 \%$ respectively. The lowest removal rate $54.4 \%$ was observed with the microfilter filled with sea sand only (control group). The explanation of these results is that greywater contained high fraction of surfactants which can easily be adsorbed on biochar, charcoal, organoclays, and sawdust. These results are in accordance with previous studies [31] [32] [33] [39] that revealed the ability of clays and organoclays to adsorb surfactants for water and saline solutions. Furthermore, the surfactants in greywater tend to form micelles that can aggregate on the sand surface or in void volume creating a hydrophobic condition that further enhance the removal of TKN. This is in accordance with Nir et al. [31] who proposed the formation of micelles under high concentrations of surfactants.

On the other hand, removal of BOD was in the range of 95\% - 99\% in all tested microfilters. This indicated the ability of microfilters to remove BOD. The explanation of these results is that the length of microfilter 4 meter enables the formation of anaerobic conditions that may activate the bacteria for biodegrading the organic molecules to a lower molecular weight or ionic fragments that can easily be excreted from the system. Similar result was observed with sand filter and wastewater treatment [22] [40]. Furthermore, COD removal was in the range of $61 \%-68 \%$. These results can be explained by the fact that microfilter is a closed system that did not allow further air flow inside the system. Similar observation was seen with sand filter and wastewater treatment [22].

Table 3. Chemical parameters (mean \pm stdv ) of 5 single microfilters.

\begin{tabular}{cccc}
\hline \multirow{2}{*}{ Sample } & \multicolumn{3}{c}{ Parameters (mg/l) } \\
\cline { 2 - 4 } & TKN & BOD & COD \\
\hline Greywater & $87 \pm 3$ & $1175 \pm 25$ & $1908 \pm 108$ \\
Sand & $39.7 \pm 0.95$ & $11 \pm 1$ & $741.5 \pm 28.5$ \\
Sand + biochar & $25.8 \pm 2.4$ & $12.5 \pm 2.5$ & $691.5 \pm 151.5$ \\
Sand + charcoal & $23.4 \pm 1.8$ & $9 \pm 1$ & $617 \pm 50$ \\
Sand + organoclay & $7.8 \pm 0.6$ & $8.5 \pm 1.5$ & $699.5 \pm 66.5$ \\
Sand + sawdust & $10.4 \pm 2$ & $47.5 \pm 2.5$ & $714.5 \pm 151.5$ \\
\hline
\end{tabular}




\subsection{Influence of Microfilter on Physical Parameters of Greywater}

Influence of microfilter on the physical parameters of greywater including $\mathrm{pH}$, Turbidity (NTU) Nephelometric Turbidity Units, electric conductivity (EC) and total dissolved salts (TDS) are shown in Table 4.

The initial $\mathrm{pH}$ value of greywater was $7.3 \pm 0.14$ and tended to be more alkaline during treatment. It reached to $8.5 \pm 0.35$. These data indicated that $\mathrm{pH}$ vaues were not dramatically changed and it remains in the acceptable range for agricultural uses, according to Palestinian Water Authority (PWA) and Food and agriculture organization of the United Nations (FAO).

On the other hand, Turbidity values were significanlly reduced due to the treatments with microflters. It has been shown that microfilters containing organoclay complexes was the best in reducing turbudity followed by charcoal and biochar. Microfilter containing sand only was better than microfilter containing sawdust. The explanation of these results is that the microfilters act as microseives that collect all suspended materials in greywater due to their larger size. In addition, due to nearly long distance of water movement $(4 \mathrm{~m})$, some biochemical reaction may have occurred which resulted in a more improvement of greywater quality. Similar observation was obtained with sand filter and wastewater treatment [22].

Furthermore, EC and TDS values were not significantly changed in response to microfilter treatments. The explanation of these resuts is that the active materials in microfilters are biochar, organoclays, charcoal, sawdust. These materials have an organic nature accordingly, weak reactions with dissolved salts in greywater were expected accordingly, low removal efficiency of EC and TDS were observed. Nevertheless, microfilter contained charcoal were the best among all probably due to its higher surface area and potential positive change with charcoal that may enhance interaction with TDS.

And charcoal was the best in removing COD, EC and TDS. The results are illustrated in Table 5.

\subsection{Effect of Treated Greywater on Plant Growth}

Effects of treated greywater on corn and tomato plant growth are shown in Table 6.

Table 4. Influence of microfilter on $\mathrm{pH}$, turbidity, EC $(\mu \mathrm{S} / \mathrm{cm})$ and TDS $(\mathrm{mg} / \mathrm{L})$ (average \pm stdev).

\begin{tabular}{ccccc}
\hline Type of microfilter & pH & NTU & EC & TDS \\
\hline Greywater & $7.3 \pm 0.14$ & $791 \pm 19.80$ & $2511 \pm 293.45$ & $1683 \pm 196.58$ \\
Sand & $8.1 \pm 0.1$ & $57.2 \pm 26.60$ & $2408 \pm 26.16$ & $1614 \pm 17.68$ \\
Sand + biochar & $8.2 \pm 0.21$ & $35.5 \pm 26.18$ & $2411 \pm 51.62$ & $1616 \pm 34.65$ \\
Sand + charcoal & $8.2 \pm 0.07$ & $34 \pm 22.42$ & $2365 \pm 89.10$ & $1585 \pm 59.40$ \\
Sand + organoclay & $7.9 \pm 0.14$ & $30.7 \pm 12.33$ & $2503 \pm 169.00$ & $1677 \pm 113.14$ \\
Sand + sawdust & $8.5 \pm 0.35$ & $77 \pm 1.41$ & $2525 \pm 111.72$ & $1692 \pm 74.95$ \\
\hline
\end{tabular}


Table 5. Best purification material compatible with PWA standards.

\begin{tabular}{ccc}
\hline Parameter & Best removing material & PWA standards [2] \\
\hline TKN & Organoclay, $7.8 \mathrm{mg} / \mathrm{L}$ & $45-100$ \\
BOD & Organoclay; $8.5 \mathrm{mg} / \mathrm{L}$ & $45-60$ \\
COD & Charcoal; $617 \mathrm{mg} / \mathrm{L}$ & $90-120$ \\
PH & Organoclay; 7.9 & $5.5-7.5$ \\
Turbidity & Organoclay $30.7 \mathrm{NTU}$ & - \\
EC & Charcoal 2365 & - \\
TDS & Charcoal $1585 \mathrm{mg} / \mathrm{L}$ & $1000-1500$ \\
\hline
\end{tabular}

Table 6. Plant length (corn and tomato) 2 weeks and 4 weeks after treatment.

\begin{tabular}{ccccccc}
\hline \multirow{2}{*}{$\begin{array}{c}\text { Time of } \\
\text { measurement }\end{array}$} & \multicolumn{2}{c}{ Corn length cm (Mean \pm std) } & \multicolumn{3}{c}{ Tomato length cm (Mean \pm std) } \\
\cline { 2 - 7 } & Tap & Grey & Treated & Tap & Grey & Treated \\
\hline 2 weeks & $14 \pm 0.82$ & $12.3 \pm 2.05$ & $17.3 \pm 2.05$ & $13.3 \pm 1.25$ & $12.6 \pm 2.05$ & $14 \pm 0.81$ \\
4 weeks & $39.7 \pm 1.25$ & $21 \pm 0.82$ & $35.7 \pm 1.69$ & $21 \pm 1.41$ & $18.3 \pm 1.25$ & $19.7 \pm 2.26$ \\
GF & 2.06 & 1.71 & 2.84 & 1.58 & 1.45 & 1.41 \\
\hline
\end{tabular}

It can be seen that irrigation with tap water (control group) and treated greywater irrigation resulted in tremendous increases in corn and tomato length whereas raw water irrigation (greywater) increased plant heights but in a lower range than tap or treated water irrigation did. Nevertheless, growth factor (GF) was the highest in corn irrigated with treated greywater and the lowest GF was with irrigation with greywater. On the other hand, GF was the highest in tomato irrigated with Tap water and the lowest was with tomato irrigated with treated greywater. The explanation of these results is that corn plant is a tolerant species and can grow under irrigation with untreated greywater. Nevertheless, treated greywater gave high GF due to the fact the treated greywater may contain soluble nitrogen compounds that can easily be absorbed by corn roots and increase the growth. The low GF with tomato plant may be due to sestivity of tomato plants. Furthermore, the effects on corn can be visualised in Figure 3 .

Figure 3 demonstrates the growth of corn under different irrigation regimes. It is obvious that irrigation with untreated greywater resulted in complete death of corn seedling after 4 weeks of irrigation whereas tap water and treated greywater irrigation kept the plant healthy and survived.

Furthermore, effects of irrigation on root system (Figure 4) indicated that greywater irrigation nearly created severe damage to the root system. The explanation of these results is due the presence of soups and surfactants that may create foams around root system and consequently reduced air exchange resulting in phytotoxicity to plants [1]. Similar observations were seen with irrigation with wastewater for other cases [22].

Influence of irrigation on tomato seedlings is visualized in Figure 5. 

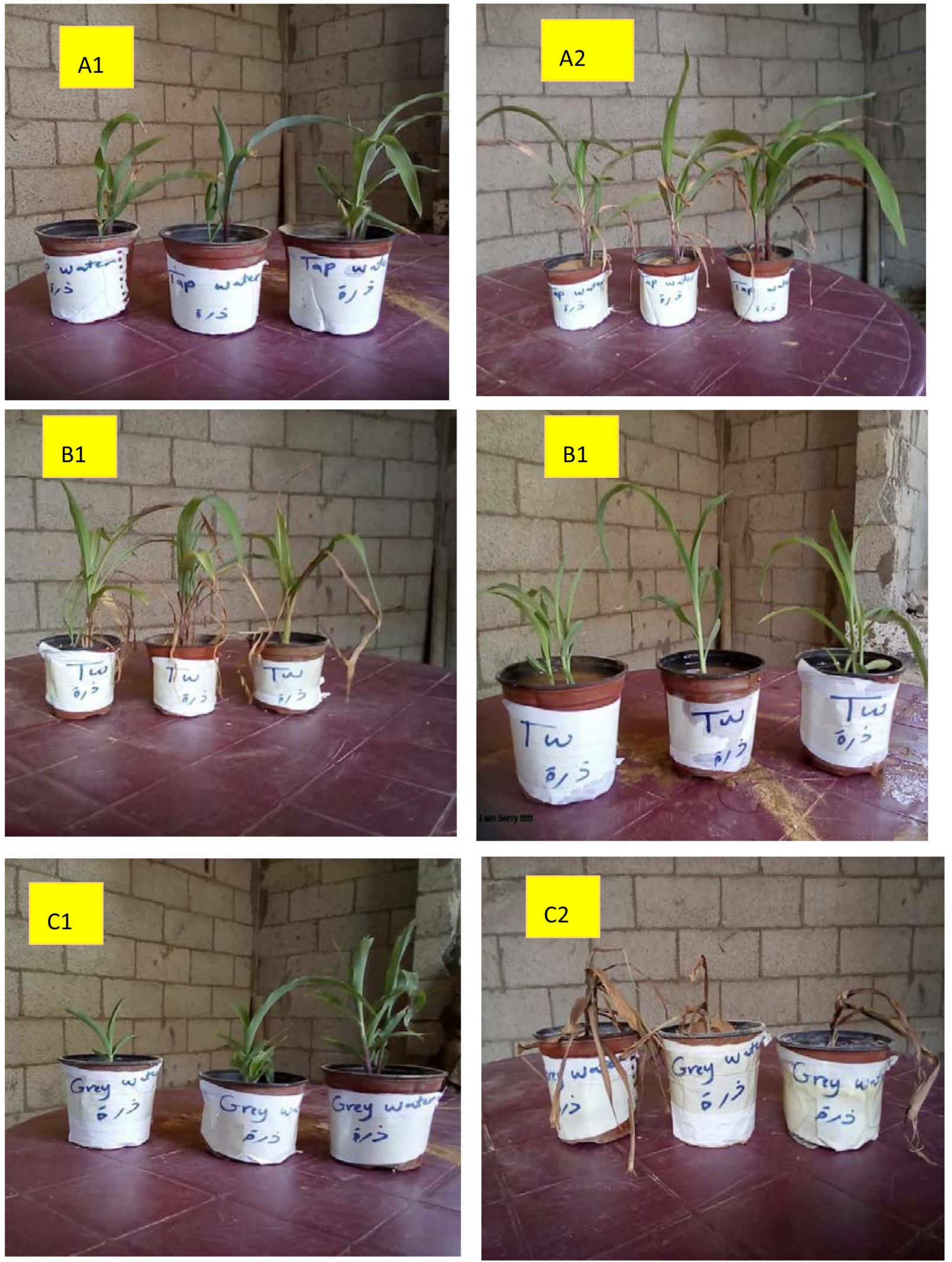

Figure 3. Corn plant grown in pot experiment irrigated with tap water (A), treated greywater (B) and irrigated with untreated greywater (C). Number 1 and 2 close to the letter indicates the first and second measurement of plant height. Measurements were done 2 and 4 weeks after treatment. 



Figure 4. Influence of greywater on corn root system. (A), (B), and (C) are corn root system grown in pot experiment irrigated with tap water, treated greywater and irrigated with untreated greywater, respectively. Measurements were done 4 weeks after treatment.

Similar to the effects on corn, irrigation with tap water (control group) and treated greywater kept tomato seedling healthy whereas untreated greywater irrigation resulted in inhibited growth. The explanation of these results is similar to that given above.

Furthermore, treated greywater can also be used for toilet flushing and for 

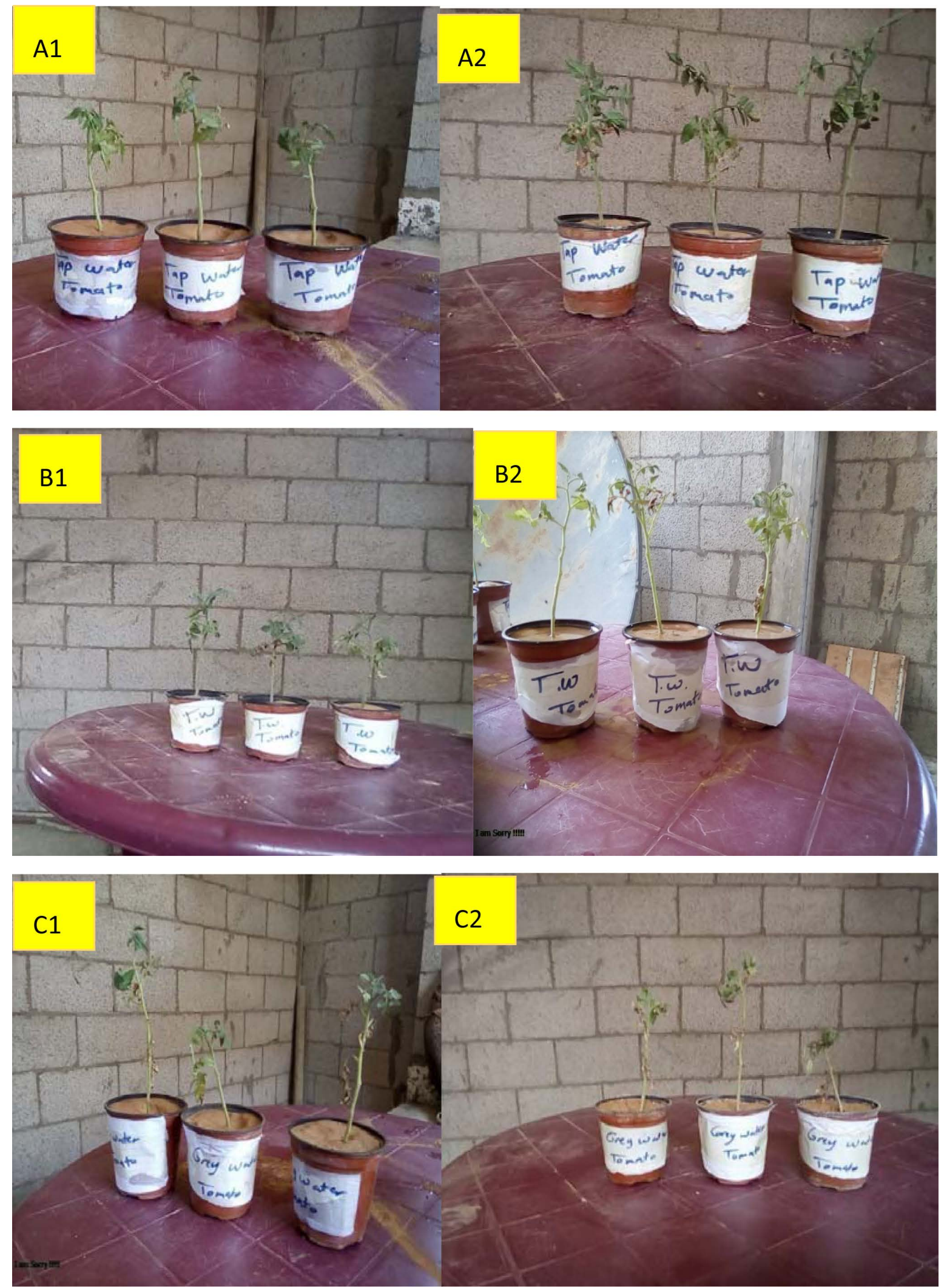

Figure 5. Tomato seedlings grown in pot experiment irrigated with tap water (A), treated greywater (B) and irrigated with untreated greywater (C). Number 1 and 2 close to the letter indicates the first and second measurement of plant height. Measurements were done 2 and 4 weeks after treatment. 
irrigation while BOD and COD is reduced obviously by treatment methods [41] [42].

Greywater treatment system may either include septic tank followed by intermittent sand filter or aerated wastewater treatment systems [43]. So far, comparison of septic tank [44], compacted sand filter [45] and microfilter (present study) are presented in Table 7.

It can be seen that removal efficiency of TKN is higher in the present study (microfilter) than other study [44] which used septic tank. Furthermore, BOD removal efficiency was best obtained by microfilter technique (this study). Additionally, COD removal is best obtained by sand filter [45] or microfilter (the present study). These results indicate the effectiveness of sandfiter or microfilter in greywater treatment. So far, it can be concluded that the present study presented a suitable, effective and applicable method for greywater treatment.

\section{Conclusions}

The proposed method of developing an advanced microfilter for greywater treatment based on mixing sea sand with biochar, organoclay, charcoal and sawdust showed interesting results. The mixture of sea sand and active materials should not be less than $0.5 \%(\mathrm{w} / \mathrm{w})$. These materials have different adsorption capacities; consequently, their removal efficiency of pollutants will follow the same order of their adsorption capacities. It has been shown that separately mixing the active materials was better than mixing them together. It appears that the microsand filter demonstrated the ability to remove different pollutants due to the micro-porosity of sea sand. Furthermore, sea sand containing organoclay complex, biochar, charcoal and/or sawdust demonstrated different abilities in removing TKN, BOD, COD and Turbidity. This was due to different surface areas and water holding capacities. The method was successful in lowering the TDS and EC. Additionally, the use of treated greywater for irrigation demonstrated the ability of corn and tomato seedlings to grow normally and above the control group (irrigation with tap

Table 7. Comparison among results produced by several authors in the literature.

\begin{tabular}{ccccc}
\hline Parameter & Kai [46] & Qadir, 2008 [44] & Almoayied [45] & Present study \\
\hline Technique & Septic tank & Septic tank & $\begin{array}{c}\text { Compacted } \\
\text { Sand Filter }\end{array}$ & Microfilters \\
$\mathrm{pH}$ & $6-9$ & $\mathrm{Nd}$ & $\mathrm{Nd}$ & $7.9-8.5$ \\
$\mathrm{TSS}$ & $<20 \mathrm{mg} / \mathrm{L}$ & $\mathrm{Nd}$ & $\mathrm{Nd}$ & $\mathrm{Nd}$ \\
Turbidity & $<5 \mathrm{NTU}$ & $\mathrm{Nd}$ & $\mathrm{Nd}$ & $30.7 \%-77 \%$ Removal \\
BOD & $<20 \mathrm{mg} / \mathrm{L}$ & $59 \%$ & $78 \%-96 \%$ & $95.96 \%-99 \%$ Removal \\
$\mathrm{COD}$ & $\mathrm{Nd}$ & $62 \%$ & $69 \%-98 \%$ & $61.14 \%-67.66 \%$ Removal \\
TKN & $\mathrm{Nd}$ & $70 \%$ & $\mathrm{Nd}$ & $54.37 \%-91.0 \%$ Removal \\
EC & $\mathrm{Nd}$ & $\mathrm{Nd}$ & $\mathrm{Nd}$ & $3.98 \%-5.81 \%$ Removal \\
TDS & $\mathrm{Nd}$ & $\mathrm{Nd}$ & $\mathrm{Nd}$ & $4.1 \%-5.82 \%$ Removal \\
\hline
\end{tabular}


water) in the case of corn, whereas in tomato seedlings, the growth was quite different due to the sensitivity of tomato to greywater irrigation. It is recommended to use treated greywater in corn irrigation.

It can be concluded that the experimental work provides encouraging results. So far, more experimental work with other crops is needed to generalize concrete results that can be applied in Gaza at a large scale. These results are promising and can be applied in corn fields.

The limitation of the study is that it neither investigated the influence of temperature in the purification process nor added results of using nano charcoal for the purification.

\section{Conflicts of Interest}

The authors declare no conflicts of interest regarding the publication of this paper.

\section{References}

[1] El-Nahhal, Y., Safi, M., Tubail, K. and Safi, J. (2013) Effect of Treated Wastewater Irrigation on Plant Growth and Soil Properties in Gaza Strip Palestine. American Journal of Plant Science, 4, 1736-1743. https://doi.org/10.4236/ajps.2013.49213

[2] Palestinian Water Authority (2012) Status Report of Water Resources in the Occupied State of Palestine.

[3] Eriksson, E., Auffarth, K., Henze, M. and Ledin, A. (2002) Characteristics of Grey Wastewater. Urban Water, 4, 85-104. https://doi.org/10.1016/S1462-0758(01)00064-4

[4] Li, F.Y., Wichmann, K. and Otterpohl, R. (2009) Review of the Technological Approaches for Grey Water Treatment and Reuses. Science of the Total Environment, 407, 3439-3449. https://doi.org/10.1016/j.scitotenv.2009.02.004

[5] Glover, S. and Hunter, A. (2010) Meeting Future Palestinian Water Needs. Palestine Economic Policy Research Institute (MAS), Ramallah.

[6] Christopher, Z., Odile, L., Eva, R. and Eberhard, M. (2018) Chemical Composition, Nutrient-Balancing and Biological Treatment of Hand Washing Greywater. Water Research, 144, 752-762. https://doi.org/10.1016/j.watres.2018.07.005

[7] Brewer, C.E., Chuang, V.J., Masiello, C.A., Gonnermann, H., Gao, X.D., Dugan, B., Driver, L.E., Panzacchi, P., Zygourakis, K. and Davies, C.A. (2014) New Approaches to Measuring Biochar Density and Porosity. Biomass and Bioenergy, 66, 176-185. https://doi.org/10.1016/j.biombioe.2014.03.059

[8] El-Nahhal, I., Al-Najar, H. and El-Nahhal, Y. (2014) Physicochemical Properties of Sewage Sludge from Gaza. International Journal of Geosciences, 5, 586-594. https://doi.org/10.4236/ijg.2014.56053

[9] White, W.B. (2012) Hydrogeology of Karst Aquifers. In: White, W.B. and Culver, D.C., Eds., Encyclopedia of Caves (Second Edition), Academic Press, Cambridge, 383-391. https://doi.org/10.1016/B978-0-12-383832-2.00054-2

[10] El-Nahhal, Y. (2003) Adsorption Mechanism of Chloroacetanilide Herbicides to Modified Montmorillonite. Journal of Environmental Science and Health, Part B, 38, 591 604. https://doi.org/10.1081/PFC-120023517

[11] El-Nahhal, Y. (2003) Adsorptive Behavior of Acetochlor on Organoclay Complexes. Bulletin of Environmental Contamination and Toxicology, 70, 1104-1111. 
https://doi.org/10.1007/s00128-003-0096-Z

[12] El-Nahhal, Y., Lagaly, G. and Rabinovitz, O. (2005) Organoclay Formulations of Acetochlor: Effect of High Salt. Journal of Agricultural and Food Chemistry, 53, 1620-1624. https://doi.org/10.1021/jf040383a

[13] El-Nahhal, I., Al-Najar, H. and El-Nahhal, Y. (2014) Cations and Anions in Sewage Sludge from Gaza Waste Water Treatment Plant. American Journal of Analytical Chemistry, 5, 655-665. https://doi.org/10.4236/ajac.2014.510073

[14] Nahhal, D., El-Nahhal, I., Najar, H., Al-Agha, M. and El-Nahhal, Y. (2021) Acidity, Electric Conductivity, Dissolved Oxygen Total Dissolved Solid and Salinity Profiles of Marine Water in Gaza: Influence of Wastewater Discharge. American Journal of Analytical Chemistry, 12, 408-428. https://doi.org/10.4236/ajac.2021.1211025

[15] Norton, J.F. (1946) Standard Methods for the Examination of Water and Sewage. 9th Edition, American Public Health Association, Washington DC, 139 p.

[16] El-Nahhal, Y., Nir, S., Polubesova, T., Margulies, L. and Rubin, B. (1998) Leaching, Phytotoxicity and Weed Control of New Formulations of Alachlor. Journal of Agricultural. Food Chemistry, 46, 3305-3313. https://doi.org/10.1021/jf971062k

[17] El-Nahhal, Y., El-Dahdouh, N., Hamdona, N. and Alshanti, A. (2016) Toxicological Data of Some Antibiotics and Pesticides to Fish, Mosquitoes, Cyanobacterial Mats and to Plants. Data in Brief, 6, 871-880. https://doi.org/10.1016/i.dib.2016.01.051

[18] El-Nahhal, I. and El-Nahhal, Y. (2021) Pesticide Residues in Drinking Water, Their Potential Risk to Human Health and Removal Options. Journal of Environmental Management, 299, Article ID: 113611. https://doi.org/10.1016/j.jenvman.2021.113611

[19] El-Nahhal, Y. (2020) Pesticide Residues in Honey and Their Potential Reproductive Toxicity. Science of the Total Environment, 741, Article ID: 139953. https://doi.org/10.1016/j.scitotenv.2020.139953

[20] El-Nahhal, I. and El-Nahhal, Y. (2022) Data on Estimation of Health Hazards Associated with Pesticide Residues in Drinking Water. Data in Brief, 41, Article ID: 107830. https://doi.org/10.1016/j.dib.2022.107830

[21] Safi, J., El-Nahhal, Y. and Safi, M. (2018) Particle Size Distribution and Hydraulic Conductivity in Coastal Non-Agricultural Land in Gaza Coastal Plain. International Journal of Geosciences, 9, 619-633. https://doi.org/10.4236/ijg.2018.910037

[22] El-Nahhal, Y., El-Dahdouh, O. and Husam, A. (2017) Influence of Sand Filter in Wastewater Treatment (a Case Study in Gaza City, Gaza Strip Wastewater Treatment Plant). Desalination and Water Treatment, 89, 118-126.

[23] Rizwan, T.N. and Shafiul, A. (2019) Biochars and Biochar Composites: Low-Cost Adsorbents for Environmental Remediation. In: Ok, Y., Tsang, D., Bolan, N. and Novak, J., Eds., Biochar from Biomass and Waste. Fundamentals and Applications, Elsevier, Amsterdam, 169-209.

[24] Chand, B.R. and Meenakshi, G. (2005) Activated Carbon Adsorption. Taylor \& Francis, Boca Raton, FL.

[25] Streubel, J. (2011) Biochar: Its Characterization and Utility for Recovering Phosphorous from Anaerobic Digested Dairy Effluent. Washington State University, Pullman. http://research.wsulibs.wsu.edu/xmlui/bitstream/handle/2376/2891/Streubel wsu 0 251E 10131.pdf? sequence $=1$

[26] Sahar, S., Dalahmeh, M.P., Vinnerås, B., Hylander, L.D., Öborn, I. and Jönsson, H. (2014) Effects of Changing Hydraulic and Organic Loading Rates on Pollutant Reduction in Bark, Charcoal and Sand Filters Treating Greywater. Journal of Environmental 
Management, 132, 338-345.

[27] El-Nahhal, Y. and Safi, J. (2004) Adsorption Behavior of Phenanthrene on Organoclays under Different Salinity Levels. Journal of Colloid and Interface Science, 269, 265-273.

[28] El-Nahhal, Y. and Safi, J. (2004) Stability of an Organo Clay Complex: Effects of High Concentrations of Sodium Chloride. Applied Clay Science, 24, 129-136.

[29] El-Nahhal, Y. and Safi, J. (2005) Adsorption of Benzene and Naphthalene to Modified Montmorillonite. Journal of Food, Agriculture and Environment, 3, 295-298

[30] El-Nahhal, Y., Abadsa, M. and Affifi, S. (2013) Adsorption of Diuron and Linuron in Gaza Soils. American Journal of Analytical Chemistry, 4, 94-99. https://doi.org/10.4236/ajac.2013.47A013

[31] Nir, S., Undabeytia, T., Yaron, D., El-Nahhal, Y., Polubesova, T., Serban, S., Rytwo, G., Lagaly, G. and Rubin, B. (2000) Optimization of Adsorption of Hydrophobic Herbicides on Montmorillonite Preadsorbed by Monovalent Organic Cations: Interaction between Phenyl Rings. Environmental Science and Technology, 34, 1269-1274. https://doi.org/10.1021/es9903781

[32] El-Nahhal, Y., Nir, S., Polubesova, T., Margulies, L. and Rubin, B. (1997) OrganoClay Formulations of Alachlor: Reduced Leaching and Improved Efficacy. Proceedings of Brighton Crop Protection Conference, 1, 21-26.

[33] El-Nahhal, Y. and Safi, J. (2008) Removal of Pesticide Residues from Water by OrganoBentonites. Proceedings of the Twelfth International Water Technology Conference, Alexandria, 27-30 March 2008, 1711-1724.

[34] Guégan, R. (2018) Organoclay Applications and Limits in the Environment. Comptes Rendus Chimie, 22, 132-141.

[35] Lee, Y.C., Park, W.K. and Yang, J.W. (2011) Removal of Anionic Metals by Amino-Organoclay for Water Treatment. Journal of Hazardous Materials, 190, 652-658. https://doi.org/10.1016/j.jhazmat.2011.03.093

[36] El-Nahhal, H., Yassin, M., Alzaharna, M., El-Nahhal, I. and El-Nahhal, Y. (2021) Extraction Methods of Cyanotoxins Aqueous Media and Sediments. American Journal of Analytical Chemistry, 12, 311-323. https://doi.org/10.4236/ajac.2021.129019

[37] Lucy, S. (2018) Removal of Heavy Metals $(\mathrm{Cu}, \mathrm{Pb})$ from Aqueous Solutions Using pine (Pinus halepensis) Sawdust: Equilibrium, Kinetic, and Thermodynamic Studies. Environmental Technology \& Innovation, 12, 91-103.

[38] Moreina, M., Noya, I. and Feijo, G. (2017) The Prospective Use of Biochar as Adsorption Matrix-A Review from a Lifecycle Perspective. Bioresource Technology, 246, 135-141. https://doi.org/10.1016/j.biortech.2017.08.041

[39] Jaynes F.W. and Boyd, A.S. (1990) Trimethylphenylammonium-Smectite as an Effective Adsorbent of Water Soluble Aromatic Hydrocarbons. Journal of the Air \& Waste Management Association, 40, 1649-1653. https://doi.org/10.1080/10473289.1990.10466811

[40] Sahar, S., Dalahmeh, M.P., Vinnerås, B., Hylander, L.D., Öborn, I. and Jönsson, H. (2012) Efficiency of Bark, Activated Charcoal, Foam and Sand Filters in Reducing Pollutants from Greywater. Water, Air, \& Soil Pollution, 223, 3657-3671. https://doi.org/10.1007/s11270-012-1139-Z

[41] Deepika, M., Pawan, L., Shankar, D, Ajay, S.D., Gangadhar, S. and Satish, W. (2011) Water Conservation Due to Greywater Treatment and Reuse in Urban Setting with Specific Context to Developing Countries. Water Resources, Conservation and Recycling, 55, 356-361. https://doi.org/10.1016/j.resconrec.2010.11.001

[42] Environment Protection Authority Victoria (2016) Annual Report 2016.

[43] Halalsheh, M., Dalahmeh, S., Sayed, M., Suleiman, W., Shareef, M., Mansour, M. and 
Safi, M. (2008) Grey Water Characteristics and Treatment Options for Rural Areas in Jordan. Bioresource Technology, 99, 6635-6641.

https://doi.org/10.1016/j.biortech.2007.12.029

[44] Qadir, M. (2008) Sustainable Management of Wastewater for Agriculture. Proceedings of the First Bridging Workshop, Aleppo, 11-15 November 2007, 141 p.

[45] Almoayied, A., Jonathan, C. and Steven, P. (2015) Assessing the Efficiency of an Innovative Method for Onsite Greywater Treatment: Drawer Compacted Sand Filter- A Case Study in Jordan. Ecological Engineering, 81, 525-533.

https://doi.org/10.1016/j.ecoleng.2015.04.042

[46] Kai, S.O., Janet, Y., Cheng, L., Phaik, E., Poh, M. and Nan, C. (2018) A Review of Greywater Recycling Related Issues, Challenges and Future Prospects in Malaysia. Journal of Cleaner Production, 171, 17-29. https://doi.org/10.1016/j.jclepro.2017.09.267 